\title{
Effect of temperature, volume of ova batches, and addition of a diluent, an antibiotic, oxygen and a protein inhibitor on short-term storage capacities of turbot, Psetta maxima, ova
}

\author{
Marc Suquet ${ }^{(a *)}$, Olvido Chereguini (b) , Marie-Hélène Omnes ${ }^{(a)}$, Inmaculada Rasines ${ }^{(b)}$, \\ Yvon Normant ${ }^{(a)}$, Isabel Pan Souto ${ }^{(a)}$, Loïc Quemener (a) \\ (a) Laboratoire de physiologie des poissons, Ifremer, Centre de Brest BP 70, 29280 Plouzané, France \\ (b) Centro Oceanográfico de Santander, I.E.O., Apdo 240, 39080 Santander, Spain
}

Received March 1, 1999; accepted July 9, 1999

\begin{abstract}
The effect of different parameters on short-term storage capacity of turbot ova was assessed over a 45-h period after ova collection for fertilization rates and over a 9-h period after ova collection for hatching rates. Increasing the volume of ova sampling from 0.5 to $2.5 \mathrm{~mL}$, as well as adding an antibiotic-antimicotic solution or oxygen did not significantly change the storage capacity of ova. Regarding the hatching rates, a higher storage ability was recorded at 8 and $13^{\circ} \mathrm{C}$, compared to $3{ }^{\circ} \mathrm{C}$. The mean composition of the ovarian fluid was determined ( $n=57$ spawns). Use of a diluent mimicking the ovarian fluid significantly decreased the storage ability as assessed by the fertilization rates but did not modify the hatching rates. Diluting ova in an artificial ovarian fluid deprived of calcium significantly decreased the fertilization and hatching rates during the storage period. Furthermore, addition or not of soybean trypsin inhibitor (Sigma $\mathrm{T} 9003$ ) to the artificial ovarian fluid deprived of calcium did not significantly change the results. Storage capacity of control batches of ova was low: at $13^{\circ} \mathrm{C}$, without any diluent and when ova were fertilized $3 \mathrm{~h}$ after stripping, the hatching rate was lowered to $62.4 \pm 29.4 \%$ (mean \pm SD) of the initial value. (C) 1999 Ifremer/Cnrs/Inra/Ird/Cemagref/Éditions scientifiques et médicales Elsevier SAS
\end{abstract}

Fish / ova / short-term storage / ovarian fluid / calcium / turbot / Psetta maxima

Résumé - Effet de la température, du volume du prélèvement d'ovules et de l'addition d'un diluant, d'un antibiotique, d'oxygène et d'un inhibiteur de protéines sur les capacités de conservation à court terme des ovules de turbot, Psetta maxima. L'effet de différents paramètres sur la capacité de conservation à court terme d'ovules de turbot a été testé durant une période de 45 h après la récolte des ovules pour étudier le taux de fécondation et $9 \mathrm{~h}$ pour le taux d'éclosion. L'accroissement du volume du prélèvement d'ovules de 0,5 à $2,5 \mathrm{~mL}$ ainsi que l'ajout d'une solution d'antibiotique-antimicotique ou d'oxygène ne modifient pas significativement la capacité de conservation des ovules. Comparée à $3{ }^{\circ} \mathrm{C}$, une capacité de conservation supérieure à des températures de 8 et $13^{\circ} \mathrm{C}$ est observée sur les taux d'éclosion. La composition du liquide ovarien a été précisée $(n=57$ pontes). L'ajout d'un diluant dont la composition est proche de celle du liquide ovarien a pour conséquence la diminution des taux de fécondation, mais pas celle des taux d'éclosion. De plus, la dilution dans le liquide ovarien artificiel dépourvu de calcium diminue significativement les taux de fécondation et d'éclosion. Lorsque les ovules sont placés en présence de liquide ovarien artificiel dépourvu de calcium, l'ajout d'un inhibiteur de la trypsine (Sigma T 9003) ne modifie pas les résultats observés. À $13^{\circ} \mathrm{C}$ et en absence de diluant, la capacité de conservation des lots d'ovules est faible : lorsque les ovules sont fécondés $3 \mathrm{~h}$ après leur récolte, le taux d'éclosion n'est plus que de 62,4 $\pm 29,4 \%$ (moyenne \pm écart type) de la valeur initiale. (C) 1999 Ifremer/Cnrs/Inra/Ird/Cemagref/ Éditions scientifiques et médicales Elsevier SAS

Poisson / ovules / conservation à court terme / liquide ovarien / calcium / turbot / Psetta maxima

* Corresponding author, e-mail: msuquet@ifremer.fr 


\section{INTRODUCTION}

The storage of fish ova after stripping can be used when gametes must be transported to synchronize gamete availability of both sexes and for gamete management including insemination operations and chromosome manipulations. Because of inadequate dehydration and toxicity of cryoprotectants, attempts to freeze fish ova have been unsuccessful up to now [31]. As a consequence, short-term storage protocols have been developed using positive temperatures (for a review, see [3] for salmonids, [24] for siluroids and [26] for carp). Most works are devoted to salmonids, showing the effect of temperature $[4,18]$ and composition of diluting media $[2,5]$ on the storage capacity of ova. The effect of both factors has also been reported in European catfish (Silurus glanis) [25] and in carp (Cyprinus carpio) [33]. Adding oxygen in containers increased the post-storage fertility of tilapia (Sarotherodon mossambicus) ova [14]. Spontaneous activation of goldfish (Carassius auratus) ova has been blocked by soybean trypsin inhibitor, providing a means to maintain ova in vitro in a viable state for a longer period [18].

In marine fish, Blaxter [7] observed that a high hatching rate of Pacific herring (Clupea pallasii) eggs was recorded for storing periods not exceeding $36 \mathrm{~h}$. The best survival was assessed when ova of this species were stored at salinities ranging from 10 to $17 \%$. Halibut (Hippoglossus hippoglossus) ova stored beyond a 6-h period showed a poor development after fertilization [1].

Management methods have been established for turbot (Psetta maxima) sperm including short- [9] and long-term [11] storage techniques. However, turbot ova management has been restricted to the description of the effect of over-ripening on ova quality [28] and to the reduction of this process [13].

The purpose of this work was to assess the effect of parameters such as the volume of ova batches, storage temperature and addition of a diluent, an antibiotic, oxygen or a protease inhibitor on ova survival during the insemination and hatching phases.

\section{MATERIALS AND METHODS}

\subsection{General procedure}

The experiments were conducted jointly in Instituto Español de Oceanografía (Santander, Spain) and in Ifremer (Brest, France). Broodstock management, sperm and ova collection were as previously described [11]. Just after gamete collection, $0.5-\mathrm{mL}$ batches of ova (approximately 500 ova) sampled from apparently good quality spawn (viability rate $>75 \%$; ova were considered viable when they showed a translucent aspect and a lack of perivitelline space through a dissecting microscope) were laid in $35-\mathrm{mL}$ cylindrical flasks and stored at $13{ }^{\circ} \mathrm{C}$. In order to maintain the initial quality of sperm samples for a $45-\mathrm{h}$ period, sperm was previously frozen in straws [11]. Using a non-limiting ratio of 30000 thawed spermatozoa per ovum and adding $0.25 \mathrm{~mL}$ seawater at $13{ }^{\circ} \mathrm{C}$, triplicate batches of eggs were inseminated according to a standardized protocol [34], 0, 3, 9, 21, 27 and $45 \mathrm{~h}$ after stripping females. Fertilization rate was assessed $3 \mathrm{~h} 30 \mathrm{~min}$ after insemination on 200 eggs (number of four-cell stage eggs/total number of eggs). Each of the six successive experiments was repeated using four different spawns: two spawns were processed in Spain and two in France. Furthermore in Spain, duplicate batches of $0.5 \mathrm{~mL}$ of eggs were transferred to 1-L beakers for incubation. Fifty per cent of the seawater volume were renewed daily. In France, duplicate batches of eggs were randomly transferred into 1-L cylindroconical incubators with a $0.05-\mathrm{L} \cdot \mathrm{min}^{-1}$ water renewal [35]. After 6 days at $13{ }^{\circ} \mathrm{C}$, the number of larvae was exhaustively counted. Hatching rate was defined as the number of larvae divided by the number of eggs transferred to incubators.

\subsection{Experimental procedure}

In order to determine the effect of different parameters on short-term storage ability of turbot ova, six successive experiments were carried out.

\subsubsection{Ova volume}

The effect of volume was tested using 0.5 - and $2.5-\mathrm{mL}$ ova batches (height of the ova layer was 2 and $5 \mathrm{~mm}$, respectively).

\subsubsection{Temperature}

To determine temperature requirements, ova samples were kept at $3{ }^{\circ} \mathrm{C}$ (on ice), $8^{\circ} \mathrm{C}$ (in a cryostat) or $13{ }^{\circ} \mathrm{C}$ (bain-marie).

\subsubsection{Oxygen}

The survival of ova was compared under oxygen or air atmosphere. Oxygen was insufflated for $10 \mathrm{~s}$ through a straw inserted in the flask cap while air was expelled through a second straw.

\subsubsection{Diluent}

In order to determine the nature of the diluent, the composition of the ovarian fluid was studied. First, ovatocrit (cell volume $\times 100 /$ total spawn volume) was determined on six spawns by measuring diameters of 30 ova (value is the mean of two diameters observed on each ovum, using a profile projector Nikon V12) for each spawn and then calculating mean ova volume, considering the cell as a sphere. Second, the composition of the ovarian fluid of several spawns $(n=57$, collected from 37 females) was determined: ovarian fluids were obtained after filtration and centrifugation at $3500 \mathrm{~g}$ for $5 \mathrm{~min}$. The osmolality and the $\mathrm{pH}$ were immediately measured. The supernatant was then frozen at $-28{ }^{\circ} \mathrm{C}$ until chemical analysis. Total protein, $\mathrm{Na}^{+}, \mathrm{K}^{+}, \mathrm{Ca}^{2+}, \mathrm{Mg}^{2+}$ and glucose content were determined. All chemical analyses were performed accord- 
ing to methods previously described [12]. The effect of a diluent was tested by the addition or not of $0.50 \mathrm{~mL}$ of an artificial ovarian fluid $(\mathrm{NaCl} 97.4 \mathrm{mM}, \mathrm{KCl}$ $7.5 \mathrm{mM}, \mathrm{CaCl}_{2} 2.1 \mathrm{mM}, \mathrm{MgCl}_{2} 2.6 \mathrm{mM}$, bovine serum albumin $6.5 \mathrm{~g} \cdot \mathrm{L}^{-1}, \mathrm{NaHCO}_{3} 25 \mathrm{mM}$ buffered at $\mathrm{pH} 8.0$, osmotic pressure $250 \mathrm{mosm} \cdot \mathrm{L}^{-1}$ ). In order to maintain similar volumes for insemination, $0.25 \mathrm{~mL}$ of seawater was added to ova batches already diluted with artificial ovarian fluid and $0.75 \mathrm{~mL}$ to ova batches deprived of that medium. Since the total volume was increased compared to the general procedure, 48000 spermatozoa were added for one ovum. The fertilization capacity of control ova batches, inseminated just after ova collection, was not significantly different between the two conditions $0.75 \mathrm{~mL}$ of seawater or $0.25 \mathrm{~mL}$ of seawater $+0.50 \mathrm{~mL}$ of artificial ovarian fluid).

\subsubsection{Antibiotic}

Antibiotic-antimicotic solution $(5 \mu \mathrm{L}$; Sigma A 5955) containing 10000 units penicillin, $10 \mathrm{mg}$ streptomycin and $25 \mu \mathrm{g}$ amphotericin $\mathrm{B}$ per $\mathrm{mL}$ was added to half of the ova batches.

\subsubsection{Calcium and soybean trypsin inhibitor}

In the last experiment, the storage capacity of ova was compared between three conditions: no artificial ovarian fluid addition, $100 \%$ artificial ovarian fluid deprived of calcium plus $2 \mathrm{mM}$ ethylene glycol tetraacetic acid (EGTA) and $100 \%$ artificial ovarian fluid deprived of calcium plus $2 \mathrm{mM}$ EGTA plus $2 \%$ soybean trypsin inhibitor (Sigma T 9003). In order to maintain similar fertilization conditions, $100 \%$ artificial ovarian fluid deprived of calcium and $2 \mathrm{mM}$ EGTA were added to control batches of ova just before fertilization. Then, 50000 spermatozoa were added per ovum.

\subsection{Statistical analysis}

All data are expressed as mean \pm standard deviation. After angular transformation, fertilization and hatching rates were compared using a three-way block ANOVA. When differences were significant $(\alpha=0.05)$, a Newman-Keuls a posteriori test was used for comparison. After angular transformation, correlations between the fertilization and hatching rates were tested using linear regression.

\section{RESULTS}

\subsection{Ova volume}

No significant differences were observed in fertilization or hatching rates using 0.5 or $2.5 \mathrm{~mL}$ ova (figure 1).

\subsection{Temperature}

The storage capacity of turbot ova was not significantly different between the three temperatures tested
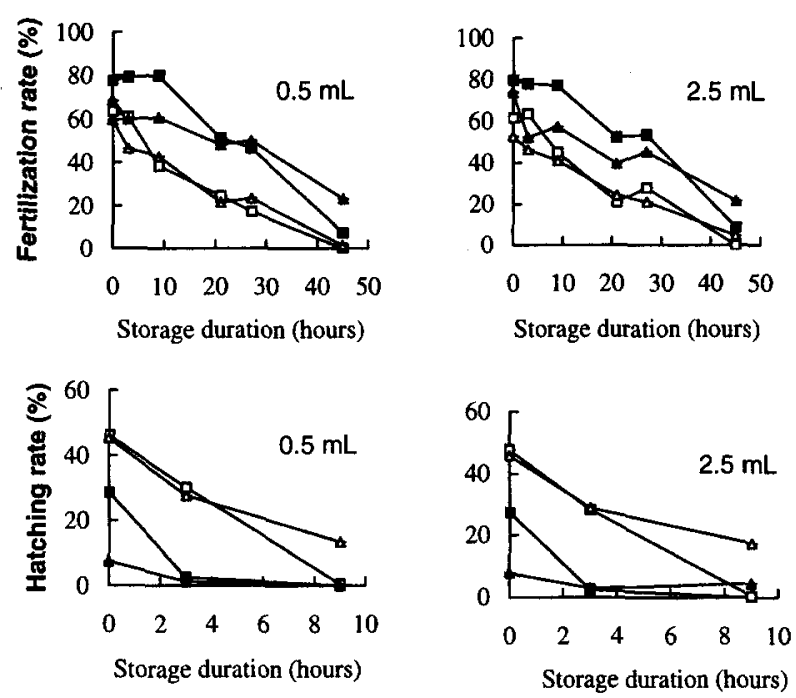

Figure 1. Effect of the volume of ova batches on the short-term storage capacity of turbot ova.

as revealed by the fertilization rates (figure 2). On the other hand, regarding the hatching rates a higher storage ability was recorded at 8 and $13{ }^{\circ} \mathrm{C}$ compared to $3{ }^{\circ} \mathrm{C}(P<0.05)$.

\subsection{Oxygen}

Adding oxygen did not increase the storage ability (figure 3).

\subsection{Diluent}

The mean ovatocrit observed on six spawns was $62.2 \pm 14.1 \%$. The mean composition of the ovarian fluid of 57 spawns is reported in table I. Use of a diluent mimicking the ovarian fluid decreased the fertilization rates $(P<0.001)$ but not the hatching rates (figure 4).

Table I. Mean composition of the ovarian fluid of 57 spawns, collected from 37 females.

\begin{tabular}{lc}
\hline & Mean $\pm \mathrm{SD}$ \\
\hline $\mathrm{Na}^{+}\left(\mathrm{mmol} \cdot \mathrm{L}^{-1}\right)$ & $97.4 \pm 22.4$ \\
$\mathrm{~K}^{+}\left(\mathrm{mmol} \cdot \mathrm{L}^{-1}\right)$ & $7.5 \pm 3.4$ \\
$\mathrm{Ca}^{2+}\left(\mathrm{mmol} \cdot \mathrm{L}^{-1}\right)$ & $2.1 \pm 1.4$ \\
$\mathrm{Mg}^{2+}\left(\mathrm{mmol} \cdot \mathrm{L}^{-1}\right)$ & $2.6 \pm 1.6$ \\
$\mathrm{Cl}^{-}\left(\mathrm{mmol} \cdot \mathrm{L}^{-1}\right)$ & $102.9 \pm 25.6$ \\
Glucose $\left(\mathrm{mmol} \cdot \mathrm{L}^{-1}\right)$ & $0.6 \pm 0.3$ \\
Protein $\left(\mathrm{mg} \cdot \mathrm{mL}^{-1}\right)$ & $6.4 \pm 4.2$ \\
Osmotic pressure $\left(\mathrm{mosm} \cdot \mathrm{L}^{-1}\right)$ & $234 \pm 55$ \\
$\mathrm{pH}$ & $7.60 \pm 0.42$ \\
\hline
\end{tabular}




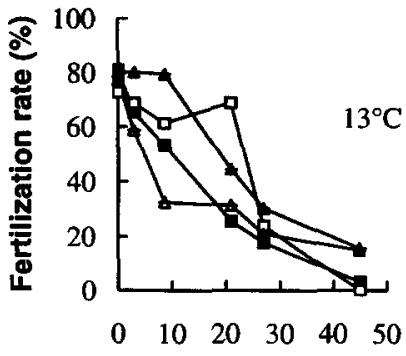

Storage duration (hours)

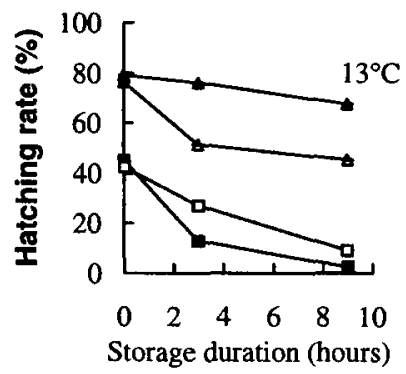

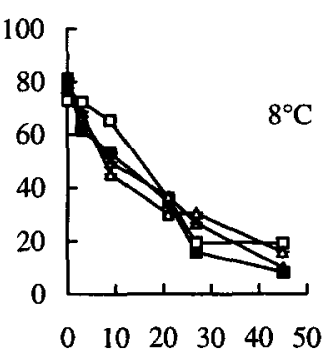

Storage duration (hours)

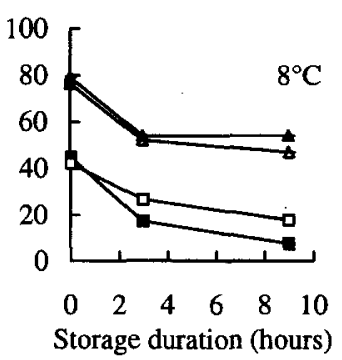

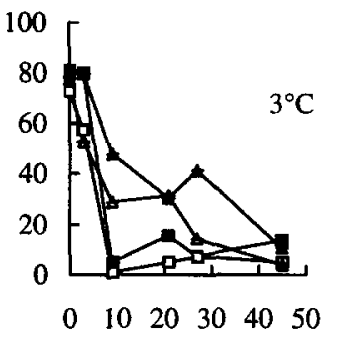

Storage duration (hours)

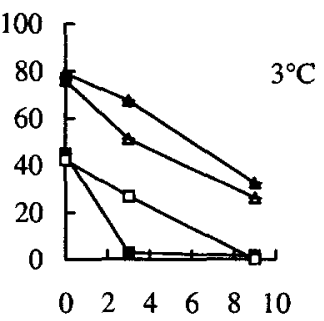

Storage duration (hours)

Figure 2. Effect of temperature on the short-term storage capacity of turbot ova.

\subsection{Antibiotic}

Adding an antibiotic did not induce any difference in storage capacity of turbot ova (figure 5).

\subsection{Calcium and soybean trypsin inhibitor}

Diluting ova in an artificial ovarian fluid deprived of calcium, significantly decreased the storage capacity (figure 6$)$ as revealed by the fertilization $(P<0.001)$
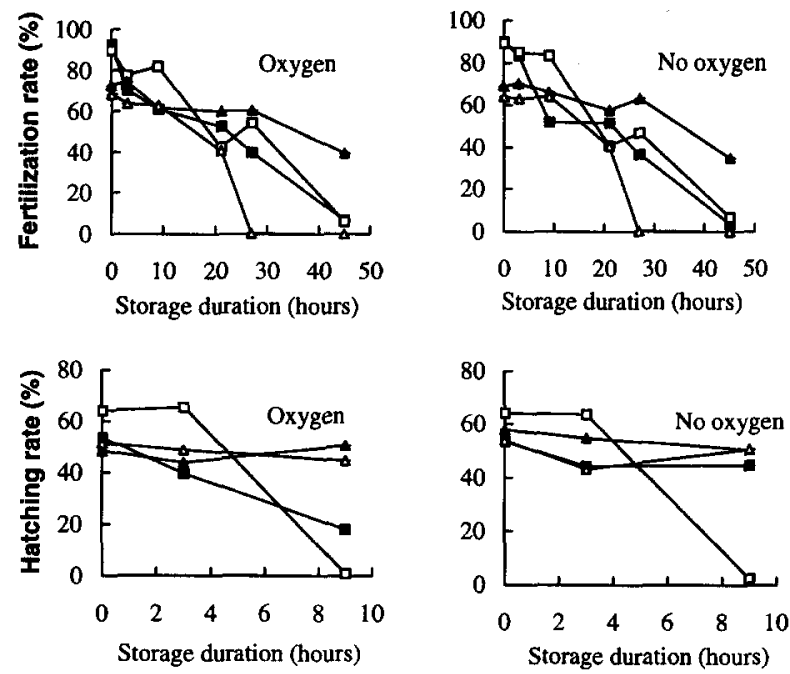

Figure 3. Effect of oxygen on the short-term storage capacity of turbot ova. and hatching rates $(P<0.01)$. A significative interaction $(P<0.001)$ was noted between blocks and media for this first parameter. Furthermore, adding an inhibitor did not change the results recorded when using an artificial ovarian fluid.

\subsection{Storage capacity of control batches of ova}

The mean decrease in fertilization and hatching rates of control batches of ova in each of the six
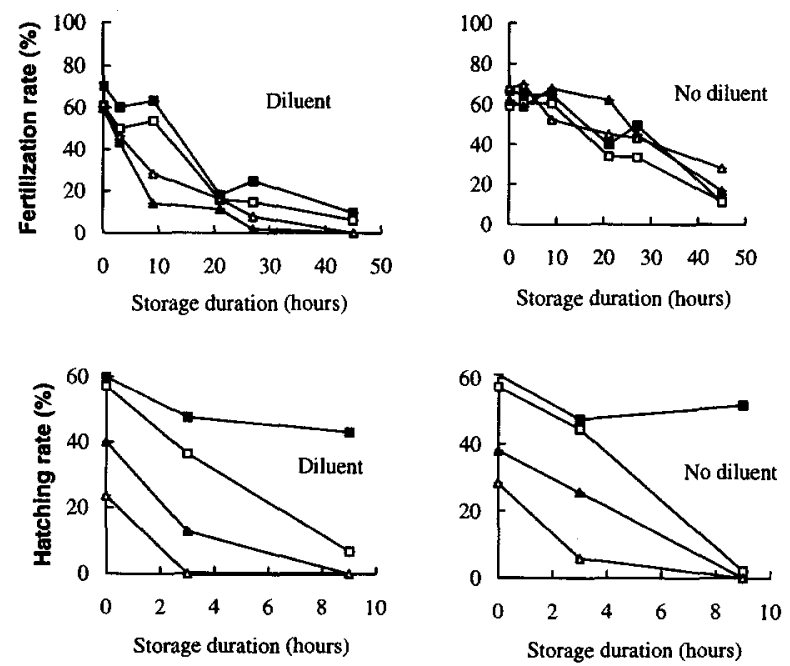

Figure 4. Effect of the presence of a diluent mimicking the ovarian fluid on the short-term storage capacity of turbot ova. 

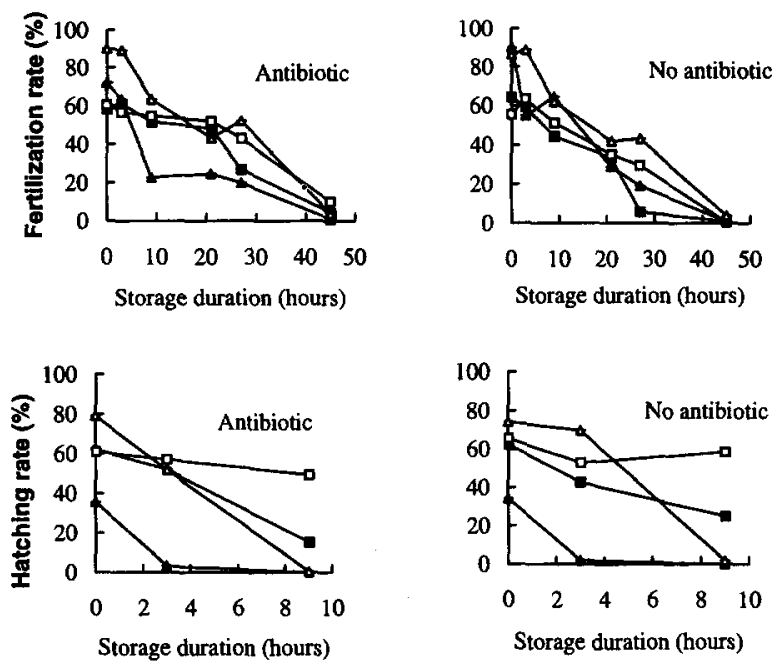

Figure 5. Effect of antibiotic on the short-term storage capacity of turbot ova.

experiments (volume: $0.5 \mathrm{~mL}$; temperature: $13^{\circ} \mathrm{C}$; no diluent; $n=24$ ) as a function of storage duration is reported in figure 7 . Under these conditions, the fertilization capacity decreased significantly after a 9-h storage period $(P<0.001)$ to $80.0 \pm 20.5 \%$ of the initial value and $57.1 \pm 19.3 \%$ after $21 \mathrm{~h}$. Furthermore, the hatching rate was significantly lowered to $62.4 \pm 29.4 \%$ of the initial value at $3 \mathrm{~h}$ and $38.1 \pm$ $37.7 \%$ after $9 \mathrm{~h}(P<0.001)$. When grouping data recorded at 0,3 and $9 \mathrm{~h}$ after stripping, a significant correlation was observed between fertilization rates $(x)$ and hatching rates $(y)$ :

$y=0.84+0.19 x(n=72, P<0.001, \mathrm{R}=0.38, \mathrm{SE}$ of estimate $=0.15$ ).

\section{DISCUSSION}

When assessing the fertilization rate of turbot eggs, blastomers become less visible and presented more frequent morphological abnormalities as the storage period progressed, suggesting a loss of ova quality. Compared to the fertilization rate, the decrease in the hatching rate as a function of time was more precocious. This observation confirms the results reported by McEvoy [28] in the same species. The fertilization capacity of Japanese flounder (Limanda yokohama) ova was high for 3 days after collection, whereas the hatching rate decreased after only $24 \mathrm{~h} \mathrm{[16].} \mathrm{This}$ delayed decrease in the fertilization rate was also reported in Pacific herring [15] and in Atlantic halibut [1]. According to observations previously published [21], this indicates that the fertilization rate of ova of some fish species is maintained for a longer period than their ability to survive the embryonic development phase. In turbot, this observation can explain the low coefficient of correlation $(R=0.38)$ observed between fertilization and hatching rates, when grouping data recorded at 0,3 and $9 \mathrm{~h}$ after stripping.

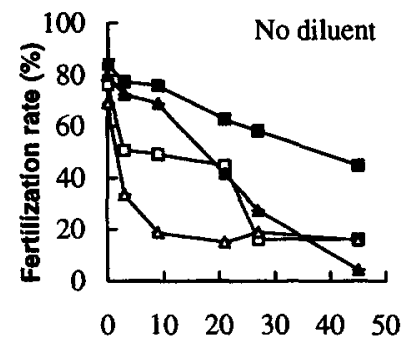

Storage duration (hours)

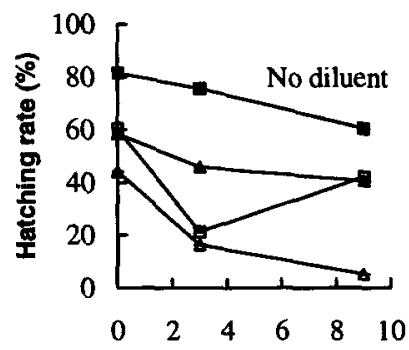

Storage duration (hours)
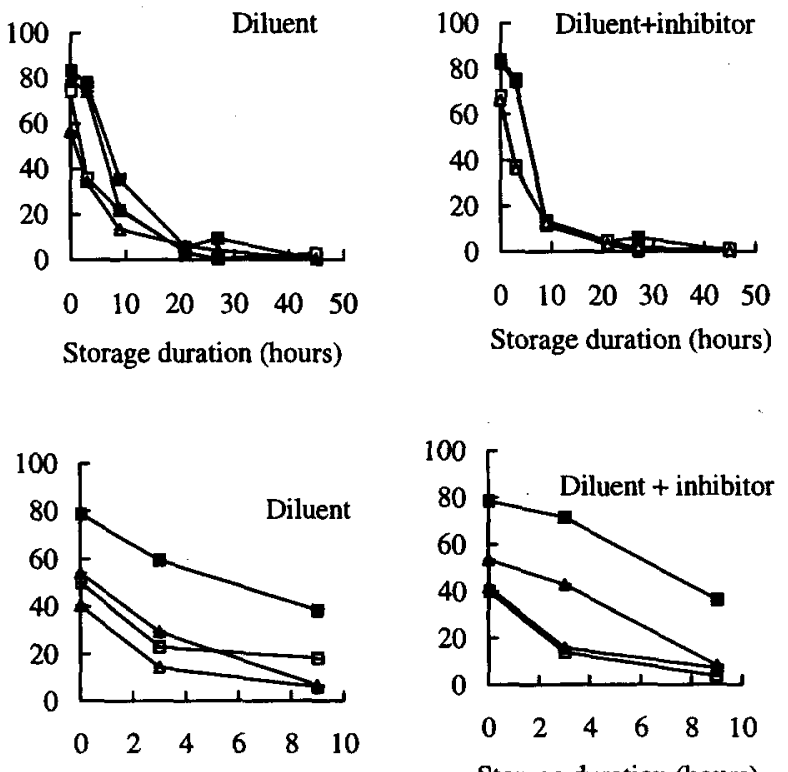

Storage duration (hours)

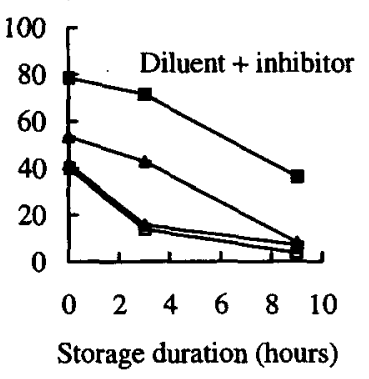

Figure 6. Effect of addition of a diluent mimicking the ovarian fluid and deprived of calcium plus $2 \mathrm{mM}$ ethylene glycol tetraacetic acid (EGTA) or of a diluent mimicking the ovarian fluid and deprived of calcium plus 2 mM EGTA plus $2 \%$ soybean trypsin inhibitor. 

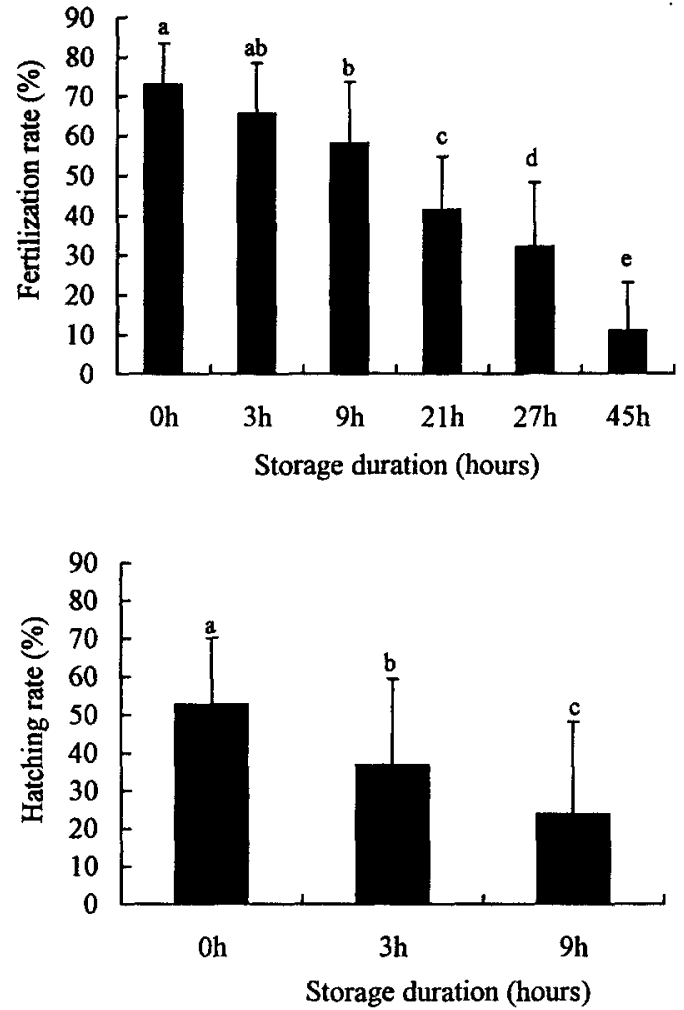

Figure 7. Changes in fertilization and hatching rates of control batches of ova (volume: $0.5 \mathrm{~mL}$; temperature: $13^{\circ} \mathrm{C}$; no diluent) as a function of storage duration.

Neither increasing the volume of ova batches from 0.5 to $2.5 \mathrm{~mL}$ nor adding oxygen changes the storage capacity of turbot ova. This result suggests a low requirement for oxygen of turbot ova. No difference was reported in coho salmon (Oncorhynchus kisutch) using air or oxygen [32]. On the other hand, a better storage capacity of chum salmon ova was observed when increasing air to gamete ratio [19]. Furthermore, adding oxygen increased the survival of tilapia ( $\mathrm{Sa}$ rotherodon mossambicus) [14] and razorback sucker (Xyrauchen texanus) ova [8].

The use of an antibiotic does not change the survival of turbot ova during the storage period. Bacteria flora (from less than 10 up to $10^{3}$ bacteria per ovum) was associated with ova of this fish species [29]. Bacteria proliferating after a 19-h storage of tilapia ova were inhibited by kanamycin sulphate [14]. However, the observed decrease in turbot ova quality during the storage period in the presence of antibiotic could rather be due to cellular lysis than to the development of bacterial flora.

Compared to $3{ }^{\circ} \mathrm{C}$, a better survival of turbot ova was assessed at 8 and $13^{\circ} \mathrm{C}$. Decreasing storage temperature from 15 to $3{ }^{\circ} \mathrm{C}$ prolonged the survival of chum salmon ova [19]. On the other hand, a higher storage capacity of grass carp (Ctenopharyngodon idella) ova was reported at $22^{\circ} \mathrm{C}$ than at $9^{\circ} \mathrm{C}$ [36]. The optimal temperature for the storage of ova is $19^{\circ} \mathrm{C}$ in European catfish (Silurus glanis) [25] and $20^{\circ} \mathrm{C}$ in tilapia [14]. Including protecting constituents in the diluent could be necessary for the storage of turbot ova at low temperatures.

Adding an artificial ovarian fluid to turbot ova did not increase their survival. Diluting rainbow trout ova in media mimicking seminal fluid or blood plasma increased their storage capacity [5]. However, sucrose solutions in which osmotic pressure was comprised between 200 and $300 \mathrm{mosm} \cdot \mathrm{L}^{-1}$ lowered ova survival in this species [2]. Adding a soybean trypsin inhibitor increased the storage ability of goldfish ova by blocking chorion expansion [18]. The use of this inhibitor did not increase the storage capacity of turbot ova. However, no spontaneous activation was observed during the storage period of ova of this species.

The osmotic pressure assessed in the ovarian fluid of turbot is low compared to other fish species: salmonids (from 256 to $292 \mathrm{mosml} \cdot \mathrm{L}^{-1}$ ) [22], carp $\left(305 \mathrm{mosml} \cdot \mathrm{L}^{-1}\right)$ [30] and marine lumpsucker $(C y$ clopterus lumpus, $359 \mathrm{mosml} \cdot \mathrm{L}^{-1}$ ) [10]. However, a low osmotic pressure was measured in the ovarian fluid of bleak, a cyprinidae (Alburnus alburnus, 237 mosml $\cdot \mathrm{L}^{-1}$ ) [23]. In turbot, mean $\mathrm{pH}(7.60)$ is also lower than values recorded in salmonids (8.4-8.8) [22] or carp (8.5) [30]. Then, high concentrations of proteins are observed in turbot compared to salmonids (from 0.95 to $2.78 \mathrm{mg} \cdot \mathrm{mL}^{-1}$ ) [22] or bleak $\left(1.58 \mathrm{mg} \cdot \mathrm{mL}^{-1}\right)$.

Compared to sperm $[6,31]$, in vitro survival of turbot ova is rather low: at $13{ }^{\circ} \mathrm{C}$, without any diluent and when ova were fertilized $3 \mathrm{~h}$ after stripping, the hatching rate was lowered to $62.4 \pm 29.4 \%$ of the control. A low storage ability of ova was also recorded in other fish species: from 1 to $6 \mathrm{~h}$ in carp [26], from 2 to $12 \mathrm{~h}$ in Siluroids [24], from 3 to $6 \mathrm{~h}$ in rainbow trout (Oncorhynchus mykiss) and $12 \mathrm{~h}$ in brown trout (Salmo trutta fario) [27], from 1 to $9 \mathrm{~h}$ in cod (Gadus morhua) [20] and $6 \mathrm{~h}$ in Atlantic halibut, Hippoglossus hippoglossus [17]. In the ovary, McEvoy [28] showed that the storage ability of turbot ova was restricted to $10 \mathrm{~h}$ after ovulation at a temperature of $12-14^{\circ} \mathrm{C}$. After a 24-h storage period in the ovary, no hatching was observed by this author.

This work shows that the viability of turbot ova decreased very rapidly during in vitro storage. Except for temperature and addition of a diluent mimicking the ovarian fluid, this first set of biotests has a low effect on the storage capacity of turbot ova. Further studies are required to improve storage ability of ova of this species, regarding the effect of parameters such as the presence of cryoprotectant at a temperature near $0{ }^{\circ} \mathrm{C}$, the composition of the diluent or the presence of light during the storage period. 


\section{Acknowledgements}

The authors thank C. Fauvel (Ifremer) for fruitful discussions on the protocol, A. Le Roux (Ifremer) and A. Severe (Ifremer) for their help during chemical analysis. We are grateful to R. Jezequel (Hôpital d'Instruction des Armées) for complementary chemical analysis.

\section{REFERENCES}

[1] Basavaraja N., Effects of stripping and fertilization methodology on egg quality in the Atlantic halibut, Hippoglossus hippoglossus (L.), thesis, University of Stirling, 1991, $67 \mathrm{p}$.

[2] Billard R., Survie des gamètes de truite arc-en-ciel après dilution dans des solutions salines ou de sucrose, Reprod. Nutr. Dev. 20 (1980) 1899-1905.

[3] Billard R., Reproduction in rainbow trout: sex differentiation, dynamics of gametogenesis, biology and preservation of gametes, Aquaculture 100 (1992) 263-298.

[4] Billard R., Gillet C., Vieillissement des ovules et potentialisation par la température des effets des micropolluants du milieu aqueux sur les gamètes chez la truite, Cah. Lab. Montereau 12 (1981) 35-42.

[5] Billard R., Jalabert B., L'insémination artificielle de la truite (Salmo gairdneri Richardson) II- Comparaison des effets de différents dilueurs sur la conservation de la fertilité des gamètes avant et après insémination, Ann. Biol. Anim. Biochim. Biophys. 14 (1974) 601-610.

[6] Billard R., Suquet M., Dreanno C., La conservation à court terme des gamètes de poissons, in: Proc. Refrigeration and Aquaculture, International Institute of Refrigeration, Coll. Biotechnica, 1996, pp. 437-442.

[7] Blaxter J.H.S., The behaviour and physiology of herring and other clupeids, in: Advances in Marine Biology, vol. I, Academic Press, London, 1963, pp. 261-293.

[8] Carmichael G.J., Williamson J.H., Gorman O.T., Tiersch T.R., Field propagation techniques for the endangered razorback sucker, N. Am. J. Fish. Manage. 16 (1996) 963-966.

[9] Chereguini O., Cal R.M., Dreanno C., Ogier de Baulny B., Suquet M., Maisse G., Short-term storage and cryopreservation of turbot (Scophthalmus maximus) sperm, Aquat. Living Resour. 10 (1997) 251-255.

[10] Davenport J., Lonning S., On the structure and function of the urogenital system of the female lumpsucker Cyclopterus lumpus L. (Teleostei: Scorpaeniformes), Proc. R. Soc. Lond. B 218 (1983) 201-210.

[11] Dreanno C., Suquet M., Quemener L., Cosson J., Fierville F., Normant Y., Billard R., Cryopreservation of turbot (Scophthalmus maximus) spermatozoa, Theriogenology 48 (1997) 589-603.

[12] Dreanno C., Suquet M., Desbruyères E., Cosson J., Le Aquat. Living Resour. 12 (4) (1999)
Delliou H., Billard R., Effect of urine on semen quality in turbot (Psetta maxima), Aquaculture 169 (1998) $247-262$

[13] Fauvel C., Omnes M.H., Suquet M., Normant Y., Enhancement of the production of turbot, Scophthalmus maximus (L.), larvae by controlling overripening in mature females, Aquac. Fish. Manage. 23 (1992) 209-216.

[14] Harvey B., Kelley R.N., Short-term storage of Sarotherodon mossambicus ova, Aquaculture 37 (1984) 391-395.

[15] Hay D.E., Effects of delayed spawning on viability of eggs and larvae of Pacific herring, Trans. Am. Fish. Soc. 115 (1986) 155-161.

[16] Hirose K., Machida Y., Donaldson E.M., Induced ovulation of Japanese flounder (Limanda yokohama) with $\mathrm{HCG}$ and salmon gonadotropin, with special references to changes in the quality of eggs retained in the ovarian cavity after ovulation, Bull. Jpn. Soc. Sci. Fish. 45 (1979) 31-36.

[17] Holmefjord I., Timing of stripping relative to spawning rhythms of individual females of Atlantic halibut (Hippoglossus hippoglossus L.), in: Lavens P., Sorgeloos P., Jaspers E., Ollevier F. (Eds.), Proc. Larvi'91, Eur. Aquac. Soc. vol. 15, 1991, pp. 203-204.

[18] Hsu S.Y., Goetz F.W., Inhibition of chorion expansion and preservation of fertility in goldfish (Carassius auratus) eggs by protease inhibitors, Can. J. Fish. Aquat. Sci. 50 (1993) 932-935.

[19] Jensen J.O.T., Alderdice D.F., Effect of temperature on short-term storage of eggs and sperm of chum salmon (Oncorhynchus keta), Aquaculture 37 (1984) 251-265.

[20] Kjorsvik E.K., Lonning S., Effects of egg quality on normal fertilization and early develmopment of the cod, Gadus morhua L., J. Fish Biol. 23 (1983) 1-12.

[21] Kjorsvik E., Mangor-Jensen A., Holmefjord I., Egg quality in fishes, in: Advances in Marine Biology, vol. 26, Academic Press, 1990, pp. 71-113.

[22] Lahnsteiner F., Weismann T., Patzner R.A., Composition of the ovarian fluid in 4 salmonid species: Oncorhynchus mykiss, Salmo trutta $f$. lacustris, Salvelinus alpinus and Hucho hucho, Reprod. Nutr. Dev. 35 (1995) 465-474.

[23] Lahnsteiner F., Weismann T., Patzner R.A., Structure and function of the ovarian cavity and oviduct and composition of the ovarian fluid in the bleak, Alburnus alburnus (Teleostei, Cyprinidae), Tissue Cell 29 (1997) 305-314.

[24] Legendre M., Linhart O., Billard R., Spawning and 
management of gametes, fertilized eggs and embryos in Siluroidei, Aquat. Living Resour. 9 (1996) 59-80.

[25] Linhart O., Billard R., Survival of ovulated oocytes of the European catfish (Silurus glanis) after in vivo and in vitro storage or exposure to saline solutions and urine, Aquat. Living Resour. 8 (1995) 317-322.

[26] Linhart O., Kudo S., Billard R., Slechta V., Mikodina E.V., Morphology, composition and fertilization of carp eggs: a review, Aquaculture 129 (1995) 75-93.

[27] Marcel J., Billard R., Matei D., Conservation des gamètes de truites arc-en-ciel et fario en conditions in vitro et post mortem, Bull. Fr. Piscic. 284 (1982) 155-161.

[28] McEvoy L.A., Ovulatory rhythms and over-rippening of eggs in cultivated turbot, Scophthalmus maximus L., J. Fish Biol. 24 (1984) 437-448.

[29] Omnes M.H., Temey Y., Daniel J.Y., Nicolas J.L., Bacterial environment of gametes and eggs of turbot (Scophthalmus maximus), in: World Aquaculture'93, Eur. Aquac. Soc., Spec. Publ. 19, 1993, 423 p.

[30] Plouidy M.G., Billard R., The chemical composition of the companion fluids of the gametes in the common carp (Cyprinus carpio), in: Richter C.J.J., Goos H.J.Th. (Eds.), Reproductive Physiology of Fish, PUDOC, Wageningen, 1982, p. 134.
[31] Rana K.J., Preservation of gametes, in: Bromage N.R., Roberts R.J. (Eds.), Broodstock Management and Egg and Larval Quality, Cambridge University Press, Cambridge, 1995, pp. 53-76.

[32] Rosenberg D.L., Fertilization success of coho salmon under various atmospheric conditions, temperature acclimatation, and temperature variations, Prog. Fish Cult. 45 (1983) 84-87.

[33] Rothbard S., Rubinshtein I., Gelman E., Storage of common carp, Cyprinus carpio L., eggs for short durations, Aquac. Res. 27 (1996) 175-181.

[34] Suquet M., Gaignon J.L., Quemener L., Normant Y., Artificial insemination of turbot (Scophthalmus maximus) eggs: a procedure for experimental purposes, in: Proc. Larvi'95, Eur. Aquac. Soc., Spec. Publ. 24, 1995, $57 \mathrm{p}$.

[35] Suquet M., Petton B., Normant Y., Dosdat A., Gaignon J.L., First rearing attemps of pollack, Pollachius pollachius, Aquat. Living Resour. 9 (1996) 103-106.

[36] Zlabek A., Linhart O., Short-term storage of noninseminated and unfertilized eggs of the common carp, grass carp and silver carp, Bul. Vyzk. Ustav Ryb. Hydrobiol., Vodnany 23 (1987) 3-11. 